\title{
フォースレート制御を用いた カテーテル誘導用マスタスレーブシステムの開発
}

\author{
井出 勝*1 Pierluigi Beomonte Zobel $^{* 2}$ Paolo Di Claudio*2 \\ 毛利誠*3 米田 隆 志*4

\section{Development of Master Slave System for Interventional Radiology with Force-Rate Control}

\author{
Masaru Ide*1, Pierluigi Beomonte Zobel ${ }^{* 2}$, Paolo Di Claudio*2, \\ Makoto Mohri*3 and Takashi Komeda*4
}

\begin{abstract}
The objective of this study is to develop a master-slave system for a catheter-guided operation, which is performed by using radiology, through the vascular system. When the master-slave system is used, the surgeon is not exposed to $\mathrm{x}$-rays during the operation. The master tool is managed by an operator away from the slave tool, which is near the patient. The system must provide a realistic picture to the surgeon, particularly in term of force information because this operation is performed by observing three-dimensional fields on a two-dimensional monitor. In this paper, we describe the development of a master slave system that involves the use of force-rate control for guiding the catheter without using force sensors. The master tool has a force-display function. This system can be controlled by force and velocity controlling; hence, this system realized an innovative mechanism and algorism. Finally, the preliminary experiment indicated that the new control method was effective. Further, the force display was stable and achieved fast response.
\end{abstract}

Key Words: Interventional Radiology, Master Slave System, Force Feedback, Force-Rate Control

\section{1. 緒言}

近年の医療現場では手術の際できるだけ患者を傷付けること なく手術を行える低侵襲医療への要望が高まって扮り, 低侵襲 外科手術（Minimally Invasive Surgery）も広く行われている. 低侵襲外科手術の一つに外科的介入放射線療法 (IVR: Interventional Radiology）がある. IVR は血管造影により見つかっ た病変部位に対して, カテーテルを用い, 局所的に薬剂の注入 や狭窄した血管を拡張させる治療などを行う手技であるＩVR を行う際は，血管造影装置を用いてX X 線による連続的な撮影が 必要であり，現場で働く医師が職業被曝してしまうお抏それがあ る.このため，医師が可能な限り被曝することなく作業ができ， 臨場感のあるカテーテル手技が行えるマスタスレーブシステム

原稿受付 2009 年 1 月 9 日

*1芝浦工業大学大学院 工学研究科 機能制御システム専攻

$* 2$ ラクイラ大学 (イタリア)

$* 3$ 毛利医院

$* 4$ 芝浦工業大学 システム理工学部

${ }^{* 1}$ Shibaura Institute of Technology, Functional Control Systems

$* 2$ DIMEG, University of L'Aquila (Italy)

${ }^{* 3}$ Mohri Hospital

${ }^{* 4}$ Shibaura Institute of Technology, Systems Engineering

口本論文は提案性で評価されました。
(MSS: Master Slave System) の開発が求められている.

本研究では, 被曝の恐れがない針刺しから血管へのカテーテ ル挿入までを医師が行い，その後手技の困難な箇所でのカテー テル誘導をIVR で行う際に, 医師がX 線装置から離れてカテー テル操作が可能な MSS の開発を目指している. カテーテル操 作は実際の手技と同様にカテーテルの捻り動作と直動動作の 2 自由度があれば手技が可能である. 一方で IVRの手技では操作 者は X 線投影された二次元血管画像から，血管の奥行きを想像 しながら手技を行うため，血管壁との接触を確認するための力 覚情報が重要である.

これまでにIVRを対象とした装置が報告されており，大きく 分けると自動で経路を辿る方法と MSS に分類される。リアル夕 イムに患者の血管内を監視し, 軌跡をカテーテルに辿らせるよう なシステム [1] では患者の安全性が保たれないため MSS で行わ せるようなシステムのほうが望ましい.しかしこれまでの IVR 用 MSS の研究では二つの問題がある. 一つ目は, カテーテル 誘導の最適な制御法が確立されていないことである. Jayender ら [2] は力-位置制御の追従性の高い圥長性のある 7 自由度ハイ ブリッドインピーダンス制御で試したが，患者の危険值以内に 抑えることができなかった。 そこで閾值を定め, 挿入ストローク を調節するような制御で行ったが, 個体差の影響の大きいシス 
テムであった．福田ら [3] はカテーテル先端にもセンサを付け, 二つの力情報からマスタへ力覚呈示ができる新しいインピーダ ンス制御法を提案したが，インピーダンス制御による微小な力 の安定した制御は困難であると報告している，以上の背景から カテーテル誘導の適切な制御法を決めなければならない. 二つ 目は，手術室に適応でき，医師側にも有利な MSS が開発され ていないことである. 谷本ら [4]の MSS シャーペン型は小型で 実用性の高いものであるが，捻りながら挿入することができな い, ノック式のためストロークが決められてしまう, 力覚検知 ができないなどの問題がある. 福田ら [3] の MSS は手術室にて 遠隔操作実験を行った例であるが，マス夕にはジョイステイッ クが使用されており，実際の手技であるカテーテルを捻り送る 動作とは異なる，スレーブツール上に力センサを備えたが，機 構が複雑で, カテーテルの体内への挿入時のみしか検出できず, カテーテル先端と血管壁の接触を示すためにカテーテル先端に もセンサを取り付けている. カテーテルは使い捨てであり,こ れではコストの面で実用化が難しい，以上の背景から，実際の 手技である捻り送る動作を連続的に行うことができ，スレーブ ッール上のみでカテーテル血管内誘導中の力覚検知のできる機 構であることが重要である。

Adrian ら [5] の実験ではカテーテル誘導などの長い操作時間 において, 力を使った感覚で操作するフォースレート制御のほ うが作業エネルギーを使わずに操作ができるとの報告がされて いる.つまりカテーテル誘導などの長い操作時間に扔いて位置 制御で確実に位置を決めていく方法よりも, 力を使った感覚で 操作するほうが疲れずに操作ができ, 位置を決めながらの操作 は集中力を使うため疲労が大きいと考えられる.

\section{2. 開発コンセプトおよび目的}

開発するMSS は挿入・捻りの 2 自由度で操作, 力覚呈示が可 能であり, それら各自由度が干渉しない機構とする. 力覚呈示 は手術タスクの操作性を向上することができる $[6]$. そのためス レーブッール側でカテーテルが血管壁との接触を検出し, マスタ 側の操作者に力覚呈示することによって, 二次元のモニ夕を三次 元に広がる血管内で操るときの操作性を向上させ, 結果として患 者の安全性を向上させることが可能であると考えられる．MSS は同位型 MSS を目指し, どちらもローラを用いた機構により挿 入動作を行う.カラーテルに接触する部品は滅菌・消毒ができる 材料を用いる．また，様々なサイズ $(2 \sim 11[\mathrm{Fr}])$ のカテーテル を操ることが可能であり, 径の均一でないカテーテルにも対応 できるようにした，さらにアクチュエータなどに使われる潤滑 油をカテーテルに付着させることのない機構が望まれ, 安全性 を増すため血管壁穿孔に対する機械的なフェイルセーフが必要 である. IVR 手技中に操作者に呈示する力は拉よそ $2[\mathrm{~N}]$ 前後 であり $[7]$ ，人の触覚は $0.5[\mathrm{~N}]$ ごとしか認識できない $[8]$. また, Thorsten らは IVR 用デバイスのための仕様を報告している [9]. これらを考慮した具体的な目標機能仕様を Table 1 に示す.

今回開発した MSS は前述のフォースレート制御法を採用し, その制御法に則した機構でかつ, 実際の手技をできる限り模擬 した機構を提案した，本システムではスレーブッール側に力検 出器を用いずにマスタッールヘ力覚呈示を行うことで, 安定し
Table 1 The functional specification

\begin{tabular}{|c|c|}
\hline Diameter of the Guide Wire Used & 2 to $11[\mathrm{Fr}]$ \\
\hline Maximum Force Thrust Direction & $2[\mathrm{~N}]$ \\
\hline Force Resolution in Thrust Direction & $10[\mathrm{mN}]$ \\
\hline Maximum Torque in Rotation Direction & $2[\mathrm{mNm}]$ \\
\hline Torque Resolution in Rotation Direction & $0.2[\mathrm{mNm}]$ \\
\hline Displacement in Thrust Direction & inf. \\
\hline Angular in Rotation Direction & inf. \\
\hline Maximum Speed in Thrust Direction & $50[\mathrm{~mm} / \mathrm{s}]$ \\
\hline Maximum Speed in Rotation Direction & $3.14[\mathrm{rad} / \mathrm{s}]$ \\
\hline Position Accuracy in Thrust Direction & less than $1[\mathrm{~mm}]$ \\
\hline Position Accuracy in Rotation Direction & less than $1[\mathrm{deg}]$ \\
\hline Sensing Capability & less than $0.1[\mathrm{~N}]$ \\
\hline
\end{tabular}

たシステムを実現させた新たな力覚呈示方法を考案した．カテー テルの挿入, 捻り操作はマス夕側に模擬のカテーテルを操作さ せることで実現した，力覚呈示するための情報としてはエンコー ダによるカテーテルの位置情報より得られ，マスタッールから の入力はカセンサを用いる. また, カテーテル挿入機構には過 負荷による血管壁への窄通を防ぐフェイルセーフが設けられて おり, 安全性が高い [10]. 本論では考案した機構によるMSS の 機械的性能評価を行い, 有用性の検討を行った.

\section{3. フォースレート制御理論}

今回用いる制御方法は従来までの力と位置の制御に使われて いるバイラテラル制御などの力と位置を制御するために別々に センサを設ける方法 [11] とは異なる. Jayender ら [2] はロボッ トマニピュレータを用い, カテーテルからの力の反作用を検出 したが, カテーテルからの反作用はとても小さく, 安定した力 覚デー夕は得られていなかった。このため, 本システムに使用 する制御法はスレーブツール側に力センサを用いずに力覚をマ スタに表現することが可能なものとした，大西らは推定反力に 基づいた力センサレス制御 [12] を提案したが, これは推定のた めに限定された条件下のみの制御手法であり，オブサーバの設 定が不可欠である。今回採用したフォースレート制御は遠隔側 の反力を推定する必要はないため，その点で有意と考えられる． フォースレート制御は力を推定せずにスレーブ系での速度変化 をセンシングさせ, 術者に操作感を呈示させることができる. 今 回採用したフォースレート制御の基本式を以下に示す。

$$
\begin{gathered}
\dot{X}_{s}=K_{c} \dot{X}_{m 1}+K_{v} \dot{X}_{m 2} \\
F_{m}=K_{f} F_{e}+K_{r} F_{s}
\end{gathered}
$$

$\dot{X}_{s}$ はスレーブッールのカテーテル把持部のカテーテル挿入 速度である，操作者がマス夕に入力した力 $F_{m}$ を用い，無負荷 状態を作る補償值である $X_{m 1}$ を算出する。 この值は $X_{s}$ との差 分を取ることで操作者への力覚呈示值である $X_{m 2}$ を得る。 $K_{c}$ と $K_{v}$ は速度ゲインである。 $F_{m}$ を目標值とした力制御は，二 つの項から成り立つ. $F_{e}$ はカテーテル手技に打ける環境変数で ある. 今回の制御では $F_{e}=0$ とした， $F_{s}$ はスレーブッールへ の出力であり, カテーテルの挿入力である. $K_{f}, K_{r}$ は力ゲイ ンである．Fig. 1 にブロック線図を示す．

\section{1 カテーテル位置決め方法}

操作者はマス夕に備わっている模擬カテーテルを操作し，そ 


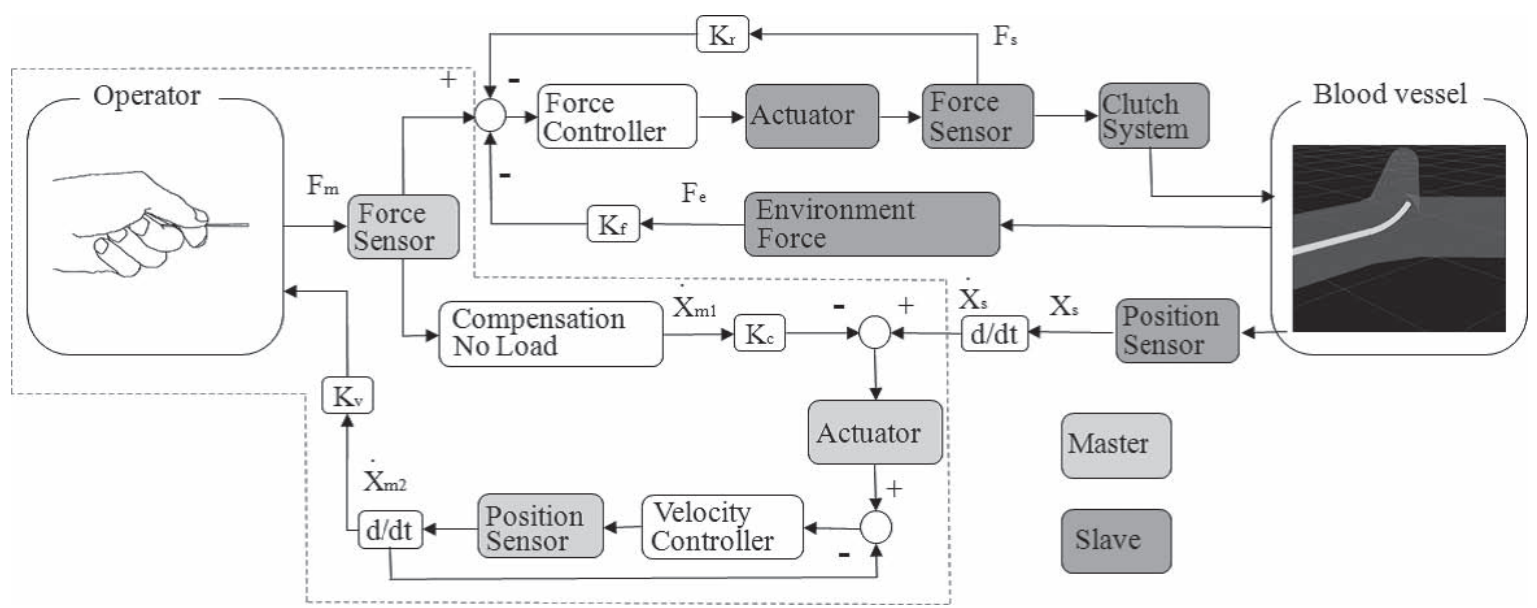

Fig. 1 Block diagram of force-rate control

のとき力センサで検出される操作力によりスレーブ動作の入力 を行う.よって力でカテーテルを操るという方法をとる. 力入 カのデータはスレーブツール側の空気圧シリンダの制御に使わ れ，そのストロークによりカテーテルの位置拉よび，速度を決 める. 久冨ら [13] の研究では力入力による MSS を開発してい るが，目標值を与えて位置のフィードバックを行わせることで 力入力による位置制御は可能であることが示唆されている.

\section{2 力覚呈示方法}

操作者が力を入力したと同時にその力情報はマスタの DC モー 夕を駆動させることで, 操作者は何も負荷のかからない状態を 作り出し, 操作者は力覚を感じない. この状態は操作者がカテー テルの挿入，捻りを行いつつ，DCモータによる動作サポートが 同時に出力されている状態である。 また，マス夕側では，エン コーダにより精密な位置制御を行わせている，力覚呈示に DC モー夕を用いれば機械的な特性である慣性, 粘性, 剛性を指定し た目標值の制御が行える [14]. カテーテル把持部（根元）の位置 (速度) データはスレーブツールに取り付けられたエンコーダに よって得る. カテーテルが血管壁に接触したとき，スレーブツー ルより得られる位置情報は変化する。そそのためマス夕側には異 なる駆動信号が入り，操作者は力を感じる，例えば $1[\mathrm{~N}]$ の力を 入力し, カテーテルは変位 $10[\mathrm{~mm}]$, 速度 $2[\mathrm{~mm} / \mathrm{s}]$ で挙動し たと仮定する。 まずマス夕はその位置情報で操作者に順方向に 捻りを与え, 力覚を感じない状態を作る。カテーテルが接触し た際，入力は $1[\mathrm{~N}]$ を越元，位置，速度は $10[\mathrm{~mm}], 2[\mathrm{~mm} / \mathrm{s}]$ 以下となり, マスタの DC モー夕は回転数が変化する. そのと きに感じる抵抗力がカテーテルからの反作用である.

血管壁を傷つけないためにマスタからの力情報はスレーブッー ルに送る前に, 制御システム内で監視をさせ, 入力情報が危険 な入力值以上の場合, スレーブツールは動作しないようにでき る. 例えばその危険な值以上の力が入力された場合はマス夕側 でランプを点灯させるなどの操作者への合図も可能である.

\section{4.マスタッール}

本研究で開発したマスタッールはサイズが H170W96D141 [mm] であり, 操作者は模擬カテーテルを操作し, 遠隔側をコントロー

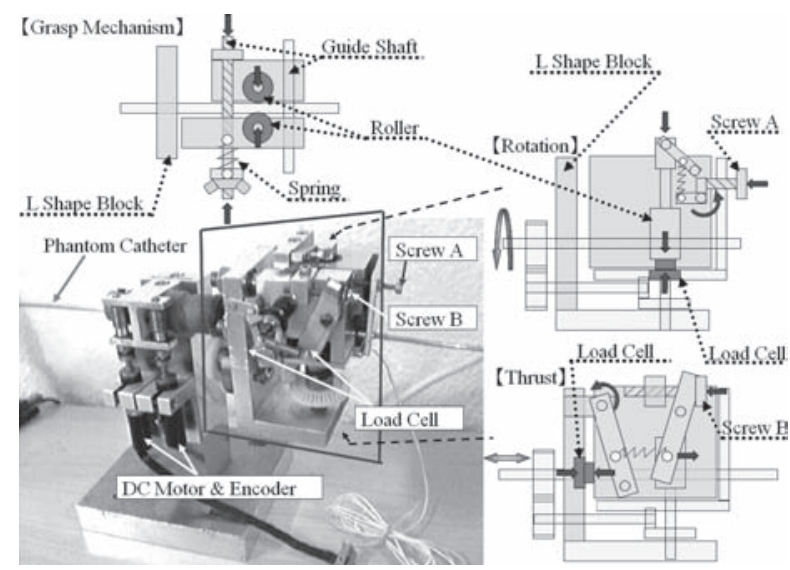

Fig. 2 Method of force detection on master

ルする。ママスタールの外観を Fig. 2 に示す.

\section{1 力入力}

Fig. 2 のように挿入方向力検知用のロードセル（共和電業, LMA-A-5N）は L 字型ブロックと把持機構部に挟まれており， その両者間にバネを設置し，そのバネの張力を調節することに よりロードセルの締め付け具合をネジ（A， B ) により調節でき る。また，捻り方向用のロードセル (共和電業, LMA-A-5N) は挿入方向用と同様に機械要素間にロードセルを設置し，バネ の張力により固定を調節させる. そして, 模擬カテーテルはゴ ム製のローラにより把持されている。 その把持部に負荷が加わ ると挿入方向, 捻り方向ともにロードセルにその負荷が直接伝 達される機構になっている。 なお， ローラによるカテーテル把 持は 2 本のガイドとバネを用いてその把持力を調節できる.

\section{2 力覚呈示}

Fig. 3 のように挿入, 捻り方向共に DC モータ（Maxon, 143897）より歯車機構を介し，模擬カテーテルの把持要素で あるローラを駆動させ, エンコーダ（66 [ppr]）によりフィード バックを行う。なお，それぞれの歯車機構にはウォームギアが 媒介されて㧍り，その特長を生かすことで操作者入力からの逆 捻りを防止し，DC モータへの負荷は与えず，かつ逆捻りによ 


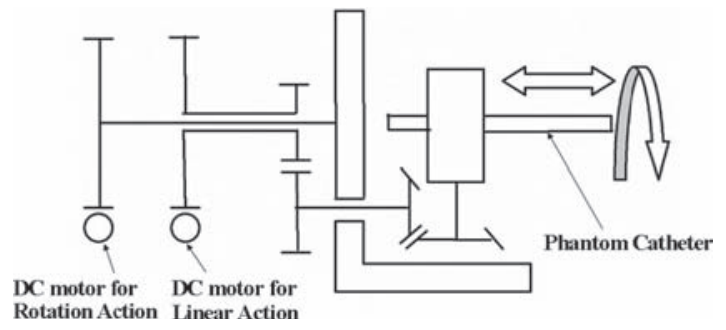

Fig. 3 Method of force display

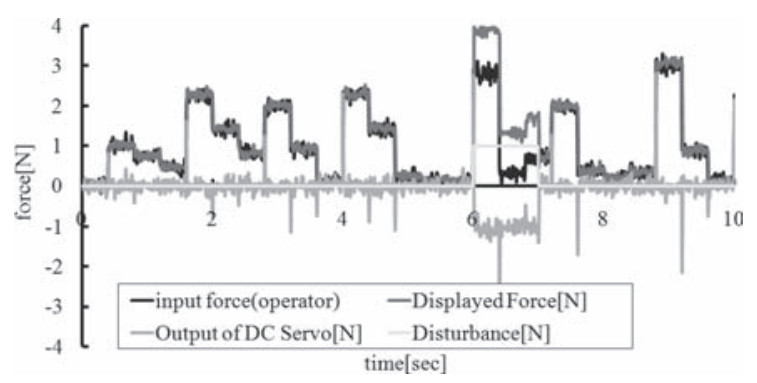

Fig. 4 Simulation result of force display

る位置のずれもない確実な力覚呈示が可能である。このように シンプルな機構で安全性を保っているシステムは力覚呈示にお いて機能性, 信頼性に優れている [10].

\section{3 シミュレーションモデルにおける力覚呈示}

新しく構築された制御手法の動作確認のため, シミュレーショ ンを行った. 方法としては, マス夕を用いた模擬カテーテル操 作中に, 感覚呈示のない状態の表現と外乱が入力された際の力 覚呈示を確認する. Fig. 1 に示された破線内のみのシミュレー ションモデルを構築し， $X_{s}$ からの信号を外乱とした. Fig. 4 に 力覚呈示シミュレーション結果を示す. ランダムに力入力がさ れている途中, 6 秒後にカテーテルが障害物に触れ, $1[\mathrm{~N}]$ の外 乱が生じたときの值の変位がステップ波入力でずれたとき操作 者の感じる力, またそのときの力覚呈示用 DC モータの挙動を 確認できた。今回の制御法での力覚呈示の有用性を確認するこ とができた。

\section{5. スレーブッール}

スレーブツールは, 患者の血管内に挿入されるカテーテルに 直接接触し，医師から与えられる手技動作を実現する．スレー ブッールには第一に安全性が求められる。また, 機構には医師 の微妙な手技動作を正確に再現するため誤差のないシンプルな 設計が求められ, 滅菌の容易さにも配慮しなければならない.

本研究で開発したスレーブツールは上記の点を考慮し, サイ ズ H165W123D101 [mm] であり, 先行研究 [3] [4] [15] と比較し て単純で小型であり, かつ力覚検知が可能である. Fig. 5 に概 観を示す. カテーテルは Fig. 5 に示すローラによって把持され, モータにより挿入方向に動作し, 捻りはローラ部全体が背部に 備わっているモータにより行わせる. 本スレーブッールは挿入, 捻りの 2 自由度を有するカテーテル誘導機構, カテーテル把持 機構, それぞれの自由度に対する力覚検知機構から構成されて いる. 回転機構は, 直動させるためのローラとそれに関連する

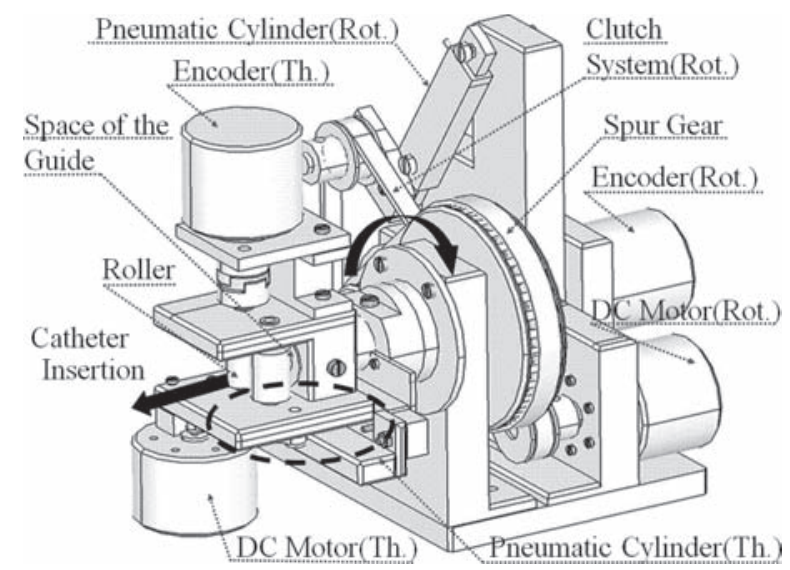

Fig. 5 Overview of slave tool

モータやエンコーダなどをまとめて回転させて捻ることが可能 である. また, カテーテルの 1 点把持で 2 自由度独立して動作 するため, 挿入, 捻り機構はそれぞれ干渉しない機構となってお り, カテーテルを捻りながら送る操作も可能である。回転軸に はブッシュを設置し, 摩擦損失の少ない回転伝達が可能である. 機構部品は強度の必要な箇所にはアルミニウム（A5052）を用 い, その他の部品はプラスチック（ABS）で構成しており, 全 体の重量は $495[\mathrm{~g}]$ である.

\section{1 滅菌対策}

カテーテル接触部分の滅菌のためにスレーブッール内に無菌 のガイドを挿入できるスペースを設置した，そのガイドはカテー テル把持部であるローラ前後に設置させることを想定しており, ガイド内は清潔野, ガイド外は不潔野となる. 実際のカテーテ ル手技は一日に何回もの手術を行うためガイドの取り替えを容 易にした。 カテーテル誘導中は血液がスレーブッールに付着す る恐れがあるが, ガイドを長くし，機構部にカバーを設けてあ るため, 付着を防ぐことが可能である. ローラの滅菌に関して だが，ローラはゴム製のため，切り込みを入れておけば，広げ て軸を包み込む形で取り付けられるため, 容易に取り換え可能 であり，ディスポーザブルとして使用できる.

\section{2 把持機構}

マスタッールと同位型を目指し，カテーテルを二つのローラ で把持させた. カテーテル手技は操作者のテクニックが重要で あり，稼動捻り範囲は様々であるため，無限挿入・捻りを行う ため, 無限軌道が可能なローラとした。

\section{3 カテーテル誘導機構}

開発した機構は摩擦車を用いたクラッチ機構とした。この機構 はプーリ, ゴムベルト, 空気圧シリンダ (SMC, CDUK6- 10S), $\mathrm{DC}$ モータ, カテーテル挿入, 捻りの位置, 速度変化を計測する ためのインクリメンタルエンコーダ (RS, RI $32,1,024$ [ppr]) から構成されている。

動作原理を Fig. 6 に示す。この図は Fig. 5 の破線部を下か ら見た図である。DC モータは一定のトルクをつねに供給させ る.このときゴムベルトはカテーテルを把持するローラ軸に触 れていないためカテーテルは動作しない. 空気圧シリンダによ りプーリがゴムベルトを押し上げ，ゴムベルトが出力軸のプー 
リに触れることによってトルクを供給する. 接触力によってゴ ムベルト, プーリ間の摩擦が変化するので伝達トルクは無段階 的に可変になり，その接触力を制御することによって間接的に ローラの回転数を制御することができる。シングルアクション の空気圧シリンダを用いることで軽量かつコンパクトな設計を 考案した．操作者から過負荷が入力された場合, カテーテルが 血管を窄通させる荷重（0.12 [N] [16]）よりもゴムベルトの接触 力は小さくなるように設計でき, この值を超えるとプーリはス リップを起こす。つまりスリップする直前の入力よりも大きな負 荷は加わらず, 患者に安全な機構である. シリンダのストロー クによりベルトがプーリに対して角度が生じたときのベルト駆 動による出力力損失の式を以下に示す.

$$
\begin{gathered}
F_{2}=F_{1} e^{\mu\left(\theta+\theta_{1}\right)} \\
\theta_{1}=\tan ^{-1}(X / M)
\end{gathered}
$$

$F_{2}$ は供給トルクによる力, $F_{1}$ はその力に抵抗する力, $\mu$ はべ ルトとプーリの静摩擦係数, $\theta$ は変位前のベルト接触間の総接 触角度, $\theta_{1}$ は変位後の角度増加量, $X$ は変位量, $M$ は Fig. 7 に示した長さである。なお, システムの動作精度はシリンダの 精度に依存する。マスタヘフィードバックするために必要な速 度変化情報としてカテーテルの位置情報の検出にエンコーダを 用いた，歪みゲージなどの力センサに比べ，ノイズが少なく安 定した力覚検知が可能である.

カテーテルが血管壁に触れたときカテーテルを把持している ローラには逆方向のトルクが働く．そのトルクはゴムベルトの

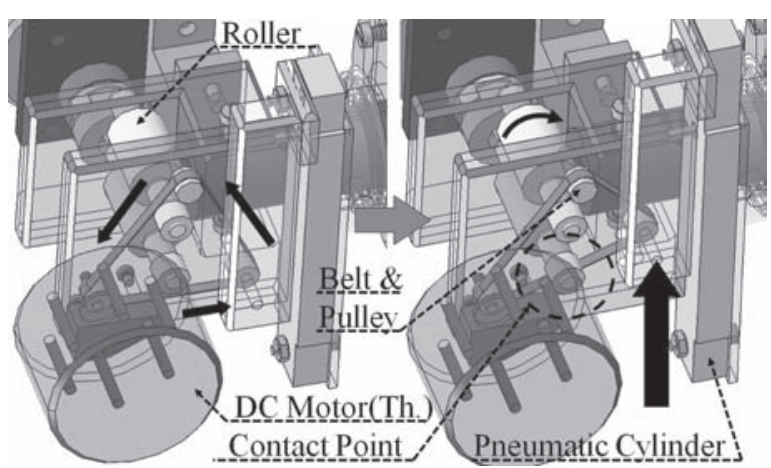

Fig. 6 Clutch system on slave tool

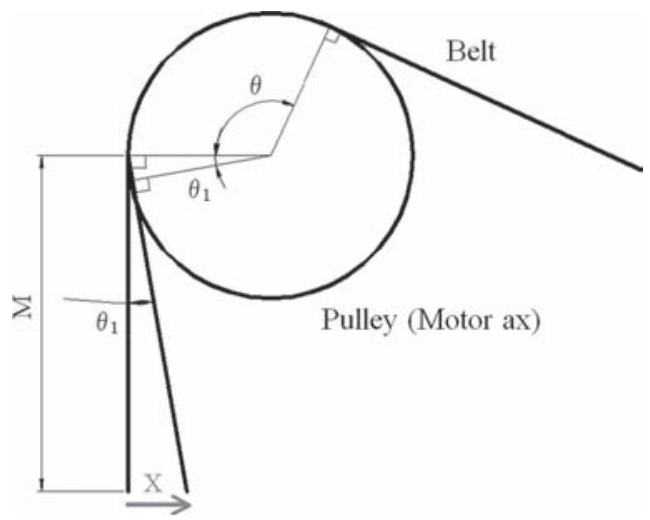

Fig. 7 Brake-band or belt friction
駆動トルクと打ち消しあい, ゴムベルトの回転は止まる。その 瞬間の MSS 間の変位差はゼロなのでマスタッールへの位置情 報もゼロになりマスタツール側の模擬カテーテルにはロックが 掛かった状態になり，それ以上前に進めることが不可能である。 それはカテーテルが壁に当たった感覚を感じさせる. 血流などの 抵抗による回転数変化も同様に押す際に重さを感じさせる.こ のカテーテル誘導機構の利点としては, 動作原理が単純であり, メンテナンス性が高い.さらにプーリ位置やゴムベルトの材質 を変更することで, 細かなパラメー夕調節が可能である. Fig. 5 の平歯車の背部に備わる機構が回転伝達機構であり, この機構 も直動機構と同様の原理で動力を伝達し, 動作する.

\section{6. 評 価 実 験}

\section{1 スレーブッール機構特性評価}

実験目的および方法 : 本研究で開発したカテーテル誘導機構 が実用的な性能を有するか検討を行った，スレーブツールに備 わっているモータを一定トルクに設定し, マスタからの力入力を 入力圧力に変換し, その圧力により空気圧シリンダのストロー クを得た。 そしてクラッチ機構を介し, カテーテル把持部に備 えられたエンコーダにより出力速度を得た，そのときの入力圧 力に対するカテーテルの出力速度の相関を確認した. また, 今 回用いた空気圧シリンダの動作特性を確認した。サンプリング レートは $1,000[\mathrm{~Hz}]$ で行った.

実験結果および考察：入力圧力に対する出力速度のヒステリ シス曲線を Fig. 8 に示す。ローラの動き始めまでに $0.12[\mathrm{MPa}]$ 以上入力しなければ動作しなかった，速度が下がり始めるのは $0.06[\mathrm{MPa}]$ ほどであり，大きなヒステリシスの影響が見られた。

この原因として空気圧シリンダの要求出力が小さすぎるため 十分な動作精度は得られなかったと考えられる. Fig. 9 に空 気圧シリンダの動作特性を示す。本シリンダの最低使用圧力は $0.15[\mathrm{MPa}]$ であり, 図に示すとおり, $0.1[\mathrm{MPa}]$ 以上の圧力を 供給しなければ動作しなかった。この予備実験結果が本実験の 結果に顕著に反映されていることが確認された。この理由とし てシリンダ内部の静摩擦が問題であり, ストロークの立ち上が りと戻るときに発生している。しかし, この挙動が安定して得 られるのならばそれを特性として制御することも可能である。

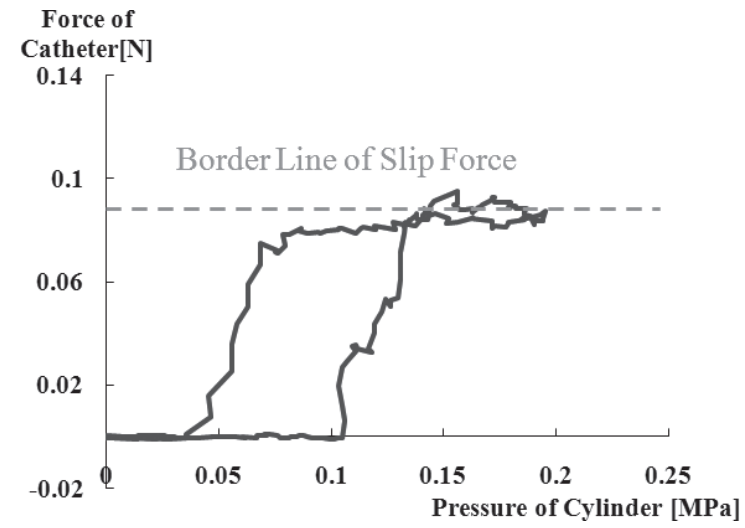

Fig. 8 Relation between force of catheter and pressure supply of cylinder 


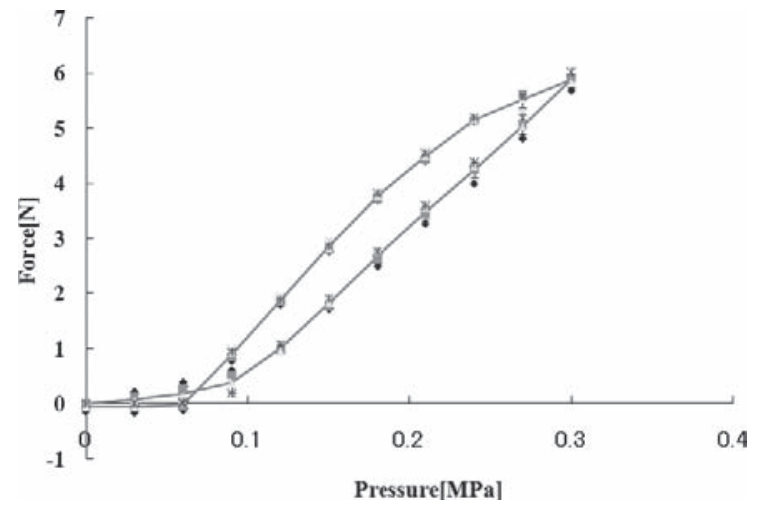

Fig. 9 Relation between force and pressure supply of cylinder

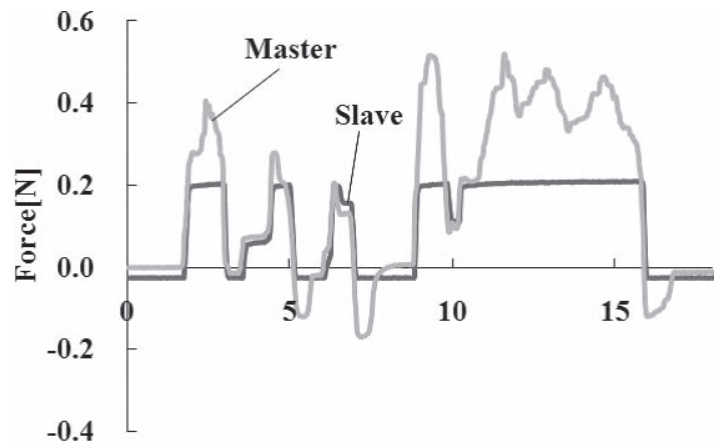

Time[sec]

Fig. 10 Experimental result of force-rate control (force)

速度の最大值は $150[\mathrm{~mm} / \mathrm{s}]$ ほどであるが，把持部の材料や径 を変更することで要求した最大速度を得ることが可能と考えら れる。

\section{2 MSS 動作評価}

実験目的および方法：提案した機構での MSS がフォースレー 卜制御を用いて実用的な動作が可能か検討した，操作者はマス タッールの挿入方向のみ模擬カテーテルを操作した. カテーテ ルは $100[\mathrm{~mm}]$ ほどに短縮させたものを用い，直線運動させた。 スレーブッール側に送られたカデータはカテーテル誘導機構を 介し, カテーテルを動作させた。 このときの挙動をエンコーダ により監視し、スレーブへの力制御，マスタへの速度制御性能 を評価した。制御は比例制御で行った。サンプリングレートは $1,000[\mathrm{~Hz}]$ で行った.

実験結果および考察：Fig. 10, Fig. 11 は力入力の追従結果 とスレーブツールからの速度情報の追従結果である. MSS 間の 力の誤差は力覚呈示と考えられ, Fig. 12 に結果を示す. Fig. 13 は速度の偏差を示す，操作感として, 挿入方向への力入力と同 時にマスタの DC モータによりサポートされるため, スレーブ 側のカテーテルに外乱が加わらなければ操作はスムーズに行う ことができた．挿入方向の前後運動も同様であった．外乱の加 わった際，遅れなど違和感のない力覚呈示ができた，外乱の大 きさに合わせ, 力覚呈示も変化した．

力入力と同時にマスタッール側の DC モータが動作し, 操作 者に無負荷の状態が実現されていることが確認でき，そのとき， $0.1[\mathrm{~N}]$ 以下の力になっていることが Fig. 12 に示された。 この

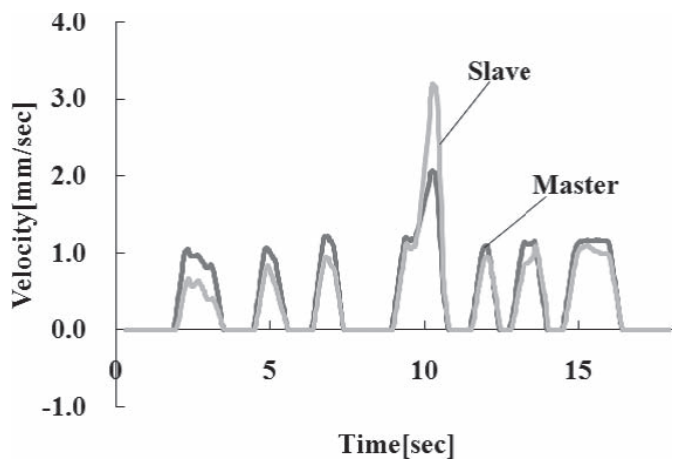

Fig. 11 Experimental result of force-rate control (velocity)

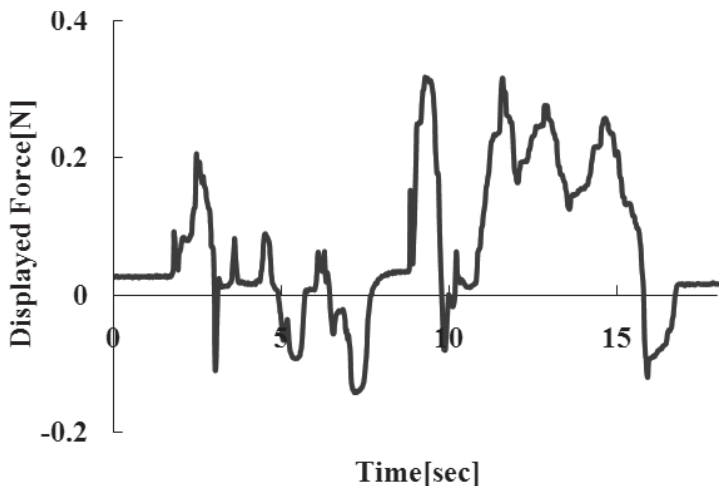

Fig. 12 Displayed force on operator

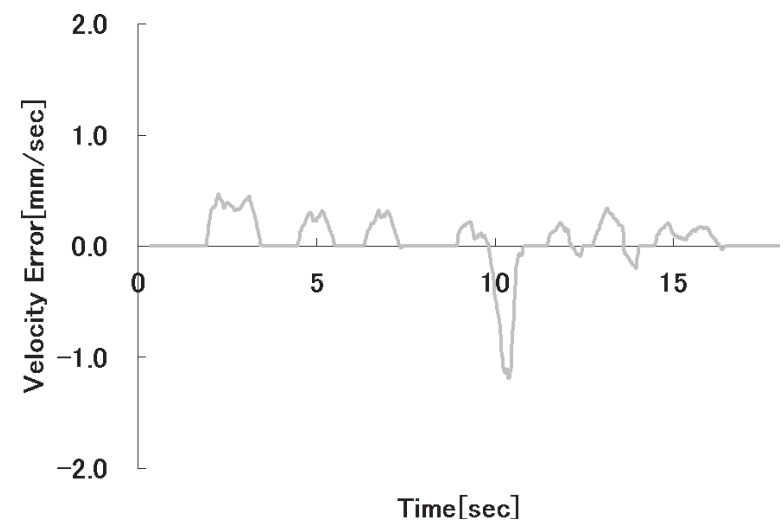

Fig. 13 Velocity error between master and slave

值を無負荷としたのは Fig. 10 での追従時のときの定常偏差のマ スタスレーブ間の差分を取った結果が 0.1 [ $\mathrm{N}]$ だったためであり， 制御次第では 0 にすることが可能である。この場合， $0.12[\mathrm{~N}]$ と $0[\mathrm{~N}]$ の違いは，微小な違いではあるが，操作者は判断でき ると考えられる. また，カテーテルに反力が加わった場合の力 覚も操作中，十分に感じることができた。

Fig. 12 に示す 0.3 [N] ほどの力が力覚呈示值である.この操 作者の感じる力はマスタッールへ入力した值とスレーブッール 側にて得られた力の差分である，スレーブッールに負荷を与え た際の挙動は $0.22[\mathrm{~N}]$ を超えるとクラッチ機構はスリップを起 こしスレーブッールの動作はストップした．操作者はこの值以 上の力を与えても模擬カテーテルを動作させることができない. 
また， $0.12[\mathrm{~N}]$ をスリップ値の目標としたが超えてしまった。簡 易的なシミュレーションにより, ベルト張力, プーリ位置の調 整は行ったが, 連続的に変化するべルト張力によるプーリとの 接触力への影響が原因であると考えられる. ただ, 本研究の焦 点は本機構の有用性の検討であるため, スリップを確認できた ことで有益であった，また，スリップが生じてもカテーテル送 りに影響がなければ問題はなく, $0.1[\mathrm{~N}]$ の誤差はプーリの位置 を変えることなどで調整可能である.

Fig. 13 に示すと扔り速度制御の結果, 応答速度, 誤差におい て十分ではなかった，速度の偏差はそのまま力覚呈示に使われ るため, 偏差が大きければ大きいほど, 操作者の感じる初期刺 激が大きくなる。一般にもとになる刺激が大きければ微妙な力 覚の違いを判別するのは困難になる $[17]$. 追従精度は制御器の 変更などで改善の余地はある. 力入力をする際, 挿入方向の入 力では押しは忠実に值を取得できるが, 引きの際に手を離して もロードセル取り付け方の問題があるため, ヒステリシスの影 響で力が残ってしまった，改善策としてロードセルを押さえて いるバネのバネ定数を変えることや，スライドガイドの摩擦の 低減に工夫が必要である。

今後は IVR 用の MSS としてカテーテルの挙動を考察する必 要が不可欠なため, カテーテルを用いた実験を行う。あらゆる 径に対応できることを確認し, システムの完成度向上に取り組 んでいく、そして，この制御方法での位置決め精度に関しての アンケート形式による定性的な評価 [18] を予定している.

\section{7. 結論}

フォースレート制御法を用いた力入力による遠隔操作と, 力 センサのない力覚検知, そしてカテーテル誘導機構の統合によ る新たな MSS を開発した，MSS 動作評価実験により，その制 御法の有用性を確認した，機械的にフェイルセーフを存在させ ることにより, 安全性を向上させ, かつ操作者への力覚呈示に も利用できる新規性の高い機構が開発された。 カセンサの代わ りにエンコーダを用い, 安定した新たな力覚呈示の可能性を示 した、しかし，今回行った実験は基礎実験のため，十分な MSS の特性が得られていない，空気圧シリンダを用いたカテーテル の制御は高精度の出力が困難であり, 別の直動アクチュエータ を選ぶことも考慮に入れなければならない。

謝 辞 本研究の一部は (財) 脳科学ライフテクノロジー研 究所の支援をいただいた。記して感謝の意を表します.

\section{参 考 文 献}

[1] C. Tercero, et al.: "Autonomous catheter insertion system using magnetic motion capture sensor for endovascular surgery," Int. J. Med. Robotics Computer Assist Surg., vol.3, issue 1, pp.52-58, 2006.

[2] J. Jayender, R.V. Patel and S. Nikumb: "Robot-AssisteDCatheter Insertion using Hybrid Impedance Control," Proc. of the IEEE Int. Conf. on Robotics and Automation, pp.607-612, 2006.

[ 3 ] M. Tanimoto, F. Arai and T. Fukuda: "Force Display Method for Intravascular Neurosurgery," Proc. of the IEEE SMC '99 Conf., vol.4, pp.1032-1037, 1999.

[4] F. Arai, R. Fujimura, T. Fukuda and M. Negoro: "New Catheter Driving Method Using Linear Stepping Mechanism for Intravascular Neurosurgery," Proc. of the IEEE Int. Conf. on Robotics and Automation, pp.2944-2949, 2002.

[5] A. Mora and A. Barrientos: "An experimental study about the effect of interactions among functional factors in performance of telemanipulation systems," Control Engineering Practice, vol.15, issue 1, pp.29-41, 2007.

[6] C.R. Wagner and R.D. Howe: "Force Feedback Benefit Depends on Experience in Multiple Dgree of Freedom Robotic Surgery Task," IEEE Trans on Robotics, vol.23, no.6, pp.12351240, 2007.

[7] A. Patriciu, et al.: "An evaluation method for the mechanical performance of guide-wires and catheters in accessing the upper urinary tract," Medical Engineering and Physics, vol.29, issue 8, pp.918-922, 2007.

[8] K.B. Shimoga: "A survey of Perceptual Feedback Issues in Dexterous Telemanipulation: Part 1. Finger Force Feedback," Virtual Reality Annual International Symposium, pp.263-270, 1993.

[9] T.A. Kern, et al.: "Design of haptic display for catheterization," Proc. of the 1st. Joint Euro Conf. and Symp. on Haptic Interfaces for Virtual Environment and Teleoperator Systems, pp.477-478, 2005.

[10] 小柳, 古荘, 井上: “力覚提示システムのための高安全性アクチュエー 夕", 日本ロボット学会誌, vol.22, no.3, pp.377-384, 2004.

[11] 横小路: “マスタ・スレーブ制御の理論”, 日本ロボット学会誌, vol.11, no.6, pp.794-802, 1993.

[12] 柴田, 磯村, 村上, 大西: “フレキシブルアームのための推定反力に基づ いた力センサレス制御”, 精密工学会誌, vol.63, no.2, pp.198-202, 1997.

[13] 久冨, 千原, 山田, 武藤：“力覚提示機能を有する遠隔作業システム に関する研究”, 岐阜県生産情報技術研究所研究報告, vol.4, 2002.

[14] 井上, 舘, 荒井: “マスタスレーブ・マニピュレータのインピーダン ス制御の一方法”, 日本ロボット学会誌, vol.10, no.4, pp.490-500, 1992.

[15] S. Guo, et al.: "A New Catheter Operating System for Medical Applications," Int. Conf. on Complex Medical Engineering, pp.82-86, 2007.

[16] 日本エム・イー学会 編: 医用電子生体工学 $\mathrm{ME}$ 辞典. p.613, コロナ 社, 1978 .

[17] 藤本, 山川, 真鍋 : “マスタスレーブにおける弁別間を考慮した力のス ケーリング”, 日本ロボット学会誌, vol.19, no.3, pp.402-407, 2002.

[18] 山田, 鴻巣, 森園, 梅谷: “自動車組立工程に㧍ける搭載作業のため のスキルアシストの提案”, 日本機械学会論文集 C, vol.68, no.666, pp.509-516, 2002. 


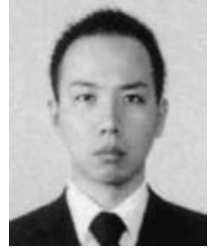

井出 勝 (Masaru Ide)

2004 年武蔵工業大学機械工学科卒業. 2007 年芝浦 工業大学大学院修士課程機械工学専攻修了. 同大学 大学院博士後期課程機能制御システム尃攻在学中, 2006 年イタリアラクイラ大学にて 1 年間研究留学. 手術用マスタスレーブシステム, 手術用トレーニ ングシステムの研究に従事. 精密工学会, 日本コン ピュー夕外科学会等の会員.

（日本ロボット学会学生会員）

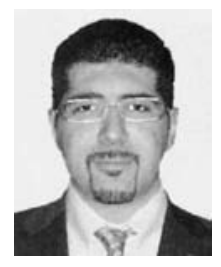

\section{Paolo Di Claudio}

was born in Ortona, Italy. He received the M.S. degree in Mechanical Engineering from the University of L'Aquila, Italy, in 2004, and the Ph.D. from the same University in 2008 with a research work on the study about thermo-mechanical phenomena during martensitic transformation of the Shape Memory Alloy. In 2002 he spent seven months at the Shibaura Institute of Technology for a students exchange program He is currently freelance engineer about Machine Design and Finite Element Method Analysis. His current research interests include Shape Memory Alloy model, modelling by FEM.

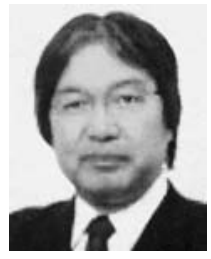

\section{米田隆志 (Takashi Komeda)}

1979 年静岡大学工学部卒業, 鈴木自動車工業 (現ス ズキ）に入社, 1984 年東京大学工学部助手, 1987 年芝浦工業大学講師, 1990 年同助教授, 1997 年同 教授. 専門はメカトロニクスをベースとした医用福 祉工学. 日本機械学会, ライフサポート学会, 日本 裖瘡学会等に所属. 工学博士.

(日本ロボット学会正会員)

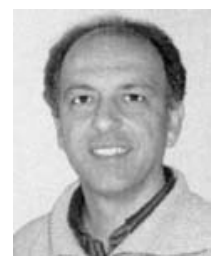

\section{Pierluigi Beomonte Zobel}

received the M.S. degree in Mechanical Engineering from the University of L'Aquila, Italy, in 1985, and the Ph.D. from the Universities of Naples and L'Aquila in 1990 with a research work on the thermodynamics of Internal Combustion Engines. Starting from the 90s he started to work in the fields of robotics and fluid power. In 1992 he spent eight months' sabbatic period at the Shibaura Institute of Technology. He is currently an associate professor of Applied Mechanics and Fluid Power at the University of L'Aquila. His current research interests include rehabilitation robotics, new actuators as Shape Memory Alloys and pneumatic muscles, agricultural automation.

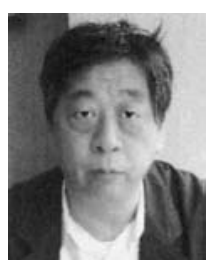

\section{毛利 誠 (Makoto Mohri)}

1972 年慶應義塾大学医学部卒業放射線科入局, 医 師免許取得 : 医籍登録番号 214818,1974 年川崎市 立川崎病院理学診療科医員, 1975 年子宮動脈造影 法の開発, 1979 年スキルス胃がんの血管造影診断 法, 1981 年国立東京第二病院放射線科勤務（現： 国立病院東京医療センター), 1983 年慶應義塾大学 放射線診断科講師, 1987 年網膜芽細胞腫に対する選択的眼動脈抗が ん剂注入療法の開発：国立がんセンター眼科と共同研究, 1992 年東 海大学医学部放射線科講師, 1997 年東海大学退職, 開業, 1998 年力 テーテル研究開発を目的とした有限会社さすら設立, 専務取締役. 医 学博士. 